\title{
1 Widespread density dependence of bacterial growth under acid stress
}

2 Francesca Fiegna ${ }^{1}$, Samay Pande ${ }^{1,2}$, Hansrainer Peitz ${ }^{3}$ and Gregory J. Velicer*1,3

$3 \quad{ }^{1}$ Institute of Integrative Biology, ETH Zurich, Switzerland

$4 \quad{ }^{2}$ Department of Microbiology and Cell Biology, Indian Institute of Science, Bangalore, India

$5 \quad{ }^{3}$ Department of Biology, Indiana University, Bloomington, IN, USA

$6 \quad{ }^{*}$ For correspondence: gregory.velicer@env.ethz.ch 


\section{ABSTRACT}

8 Benefits of cooperation intrinsically depend on density because biological interaction requires

9 organismal proximity. Microbial cooperative traits are common, yet systematic tests for a shared

10 cooperative phenotype across diverse species are rare, as are direct tests for the Allee effect -

11 positive density dependence of fitness. Here we test for positive density dependence of growth

12 under acid stress in five phylogenetically widespread bacterial species - three Gram-negative and

13 two Gram-positive - and find the Allee effect in all five. However, social protection from acid

14 stress appears to have evolved by different mechanisms across species. In Myxococcus xanthus,

15 the acid-stress Allee effect is found to be mediated by pH-regulated secretion of a diffusible

16 molecule present in supernatant from high-density cultures. In contrast, growth from low density

17 under acid stress by the other species was not enhanced by high-density supernatant.

18 Additionally, density dependence of Myxococcus fruiting-body formation during starvation is

19 found to increase with acid stress, suggesting that abiotic stresses other than starvation shape the

20 evolution of aggregative development. Our findings suggest that high cell density may protect

21 against acid stress in most bacterial species and in Myxococcus may promote predation on

22 microbes that acidify their local environment by secretion of metabolic byproducts.

23 Key words - Allee effect, eco-evo-devo, public goods, social evolution, stress response 


\section{INTRODUCTION}

Organismal density often greatly affects survival and reproduction, both positively and negatively

[1-4]. Such density dependence of fitness can mediate selection both on dispersive and aggregative

traits that modify density per se and on other traits with density-sensitive fitness effects. A positive relationship between fitness and density - the Allee effect - is observed under some ecological conditions in many species [5-16].

Beneficial fitness effects of high density can be byproducts of simple organismal proximity. For example, organismal proximity can reduce heat or water loss, locomotion costs or predation risk [1,10,17-21]. Positive density-dependence (PDD) of fitness can also derive from social traits that are selectively favoured, at least in part, due to fitness benefits conferred on others by individuals expressing the focal trait $[22,23]$. Fitness benefits derived from conspecific interactions can be demonstrated experimentally by two distinct approaches. One approach is to demonstrate that interaction between individuals of distinct genotypes increase the fitness of a focal individual (or genotype) relative to its performance under identical conditions in the absence of inter-genotype interaction, even if total population density is held constant $[24,25]$. An alternative approach is to manipulate total population density and thereby demonstrate that average fitness increases with density [26,27].

Microbes express many traits known or hypothesized to benefit their conspecifics, including quorum-sensing signals that regulate gene-expression responses to environmental cues [28,29]. However, relatively few studies have directly demonstrated positive density-dependence (PDD) of population growth by manipulating cell density [7,30-32] with strains not artificially engineered to exhibit such PDD [28,33-35]. Fewer still have investigated relationships between density and fitness in microbial populations under stress imposed by fundamental abiotic environmental parameters such as $\mathrm{pH}$, temperature and hydration [33,36-38], despite the major roles such forces have played in the evolution of microbial life. Here we experimentally examine the fitness response of several bacterial species to variable density across environments varying in $\mathrm{pH}$, an important selective force across microbial habitats that varies greatly across both large and small spatio-temporal scales and strongly

50 affects microbial community composition [39,40]. Acidity in particular is a common microbial stressor, 
under acid stress. However, the phylogenetic generality of density-dependent growth under acid stress has not, to our knowledge, been tested systematically.

We first examine interactive effects of density and $\mathrm{pH}$ on growth by Myxococcus xanthus, a bacterium that exhibits unusually sophisticated cooperative traits among prokaryotes [42] and pervades terrestrial soils [43]. M. xanthus employs two distinct motility mechanisms with social components $[44,45]$, preys on other microbial species [46] and forms multicellular fruiting bodies upon starvation $[47,48]$. The effectiveness of several M. xanthus behaviours is positively density dependent, including motility requiring Type IV pili, fruiting-body development, spore germination and growth on nonhydrolysed macropeptides [26,27,29,49,50]. M. xanthus predatory efficiency has also been hypothesized to depend positively on density [50].

After demonstrating that $M$. xanthus growth and development become increasingly dependent on density with increasing $\mathrm{pH}$ stress, we test whether such PDD of growth under acid stress is a common bacterial trait by examining four additional diverse bacterial species. We additionally investigate whether observed acid-stress Allee effects are mediated by diffusible "public good" secretions.

\section{Methods}

\section{Strains}

M. xanthus strain GJV1 is a direct descendant of the lab-reference strain DK1622, from which it differs by only several point mutations [51]. GJV1 is proficient at two M. xanthus motility systems type IV-pili driven S-motility and A-motility, which can drive single-cell movement $[44,52,53]$. Strain DK3470 has a mutation that blocks production of extracellular matrix compounds required for cell-cell cohesion, full motility and development [54]. Strains of the Gram-positive species Arthrobacter globiformis (high-GC subdivision) and Micrococcus luteus (low-GC subdivision) and of the Gramnegative species Pseudomonas fluorescens (gamma subdivision) and Rhizobium vitis (alpha subdivision) used here are the same as those reported by Morgan et al. [55].

\section{Media and culture conditions}

For all species, CTT liquid (1\% casitone; $8 \mathrm{mM} \mathrm{MgSO} 4 ; 10 \mathrm{mM}$ Tris- $\mathrm{HCl}, \mathrm{pH}$ 7.6; $1 \mathrm{mM}$ potassium phosphate) [56] and CTT agar were used as growth media, agar plates were incubated at $32{ }^{\circ} \mathrm{C}$ and $90 \%$ 
$\mathrm{rH}$ and liquid cultures were incubated at $32{ }^{\circ} \mathrm{C}$ while shaking at $300 \mathrm{rpm}$. For M. xanthus development assays, TPM liquid (identical to CTT liquid except lacking Casitone, the sole carbon source in CTT) and TPM agar (1.5\%) plates were used. Media $\mathrm{pH}$ was adjusted with $\mathrm{NaOH}$ or $\mathrm{HCl}$ to the appropriate level before autoclaving. For M. xanthus growth cultures, samples from frozen stocks were inoculated and incubated CTT hard (1.5\%) agar plates for three days. An inoculum from each plate was then transferred into eight $\mathrm{ml} \mathrm{CTT} \mathrm{liquid} \mathrm{in} \mathrm{a} 50 \mathrm{ml}$ flask and grown overnight. These exponential-phase cultures were then transferred into larger volumes of CTT (culture/flask volume always 0.16) and allowed to grow further until populations exceeded the minimum requisite size. Cell densities of exponential-phase cultures were estimated with a TECAN Genios ${ }^{\mathrm{TM}}$ plate reader. Cultures were then centrifuged (5000 rpm, $15 \mathrm{~min}$.) and resuspended to predicted densities of $\sim 1.25 \times 10^{6}, 1.25 \times 10^{8}$ or $1.25 \times 10^{10}$ cells $/ \mathrm{ml}$ with CTT liquid. For other species, samples from frozen stocks were inoculated directly into CTT liquid.

91

\section{Growth assays}

OD (optical density)-based growth-rate assays reported in Fig. S1 were performed for M. xanthus strain GJV1. Cultures were grown in Greiner ${ }^{\mathrm{TM}}$ 6-well plates containing $5 \mathrm{ml}$ of CTT agar per well, which was poured one day prior to inoculation and kept at room temperature overnight. Two wells of each plate were inoculated with $200 \mu$ of culture containing $\sim 2.5 \times 10^{5}$ (low density, LD), $\sim 2.5 \times 10^{7}$ (intermediate density, ID) or $\sim 2.5 \times 10^{9}$ (high density, HD) cells. Plates were gently rotated until the inoculated culture was spread evenly over the agar surface. The spread liquid cultures were then allowed to dry at room temperature in a laminar flow hood prior to capping the plates. OD values of each well were measured immediately after drying using a TECAN Genios ${ }^{\mathrm{TM}}$ plate reader and reflect the average of 16 reads per well in a 4 x 4 matrix. Further OD readings were taken every $12 \mathrm{~h}$ through $96 \mathrm{~h}$. Three temporally separate biological replicates were performed with two technical replicates performed within each biological replicate. OD values from within-block technical replicates were averaged prior to statistical analysis across independent replicates. Maximum growth rate for each inoculation density $\mathrm{x} \mathrm{pH}$ combination was calculated as the average slope of $\ln (\mathrm{OD})$ across replicates for the 24-hour interval spanning the fastest average growth for the respective combination (Fig. S1). 
Growth-rate assays with strain DK3470 were based on direct colony counts after dilution plating of

107 harvested and dispersed cultures. $10 \mathrm{ml}$ aliquots of CTT 1.5\% agar at $\mathrm{pH} 5.0,6.0$ and 7.5 were poured

108 into $50 \mathrm{ml}$ Erlenmeyer flasks and allowed to solidify one day prior to the beginning of the growth assay.

109 Flasks were kept covered at room temperature. $400 \mathrm{ul}$ of resuspended DK3470 culture containing

110 approximately $1.25 \times 10^{6}$ (low density, LD), $1.25 \times 10^{8}$ (intermediate density, ID) or $1.25 \times 10^{10}$ (high

111 density, HD) cells/ $\mathrm{ml}$ were spread onto the agar surface and allowed to dry in a laminar flow hood for

112 approximately 30 minutes. Due to destructive sampling, multiple flasks were prepared for each

113 combination of $\mathrm{pH}$ and initial cell density. Immediately after the $30^{\prime}$ drying period and after periods of

114 incubation shown in Figs. 1 and S1, $1 \mathrm{ml}$ of CTT liquid and $\sim 10$ glass beads ( $3 \mathrm{~mm}$ diameter) were

115 placed in each flask and flasks were shaken for $10^{\prime}$ at $300 \mathrm{rpm}$ to disperse cells. Suspended cultures

116 were then dilution plated into CTT $0.5 \%$ agar plates and resulting colonies were counted after

117 incubation at $32{ }^{\circ} \mathrm{C}$. Values shown in Fig. S1 indicate estimates of viable cell density in the 1-ml

118 harvested suspensions.

119 For the four non-myxobacterial species, preliminary experiments identified acidic $\mathrm{pH}$ ranges at

120 which growth in CTT liquid occurred but was substantially reduced in populations inoculated at a high

121 initial density. Starting from initial densities (detailed below) differing by a factor of $10^{4}$, growth at a

$122 \mathrm{pH}$ value in the relevant range for each specieswas subsequently analysed: A. globiformis at $\mathrm{pH} 4.35$,

M. luteus at $\mathrm{pH} 5.75$, P. fluorescens at $\mathrm{pH} 4.6$, and $R$. vitis at $\mathrm{pH} 4.25$. Five $\mathrm{ml}$ of CTT $1.5 \%$ agar

124 adjusted to the relevant $\mathrm{pH}$ for each species were poured into 6-well plate wells 24 hours prior to initiating growth assays. After agar solidified, a polyamide membrane filter (NL 16 Whatman $^{\mathrm{TM}}$ membrane filters, $25 \mathrm{~mm}$ diameter, $0.2 \mu \mathrm{m}$ pore size) was placed on the agar surface of each well.

127 Multiple wells were prepared for each replicate assay of each treatment because one filter was

128 destructively sampled at each time point of each assay. Cultures were grown on filters in these assays

129 because cells could not be easily harvested directly from the agar surface due to agar instability caused

130 by acidity.

131 Cultures of each species were inoculated from freezer stocks and grown overnight in CTT liquid,

132 centrifuged at $5000 \mathrm{rpm}$ for 15 minutes and resuspended with CTT liquid to high density (HD, average

133 cross-replicate densities of $\sim 1.6 \times 10^{9}$ cells $/ \mathrm{ml}$ for A. globiformis, $\sim 5.8 \times 10^{8}$ cells $/ \mathrm{ml}$ for $M$. luteus, $\sim 1.3$ 
$134 \times 10^{9}$ cells $/ \mathrm{ml}$ for $P$. fluorescens and $\sim 1.7 \times 10^{9}$ cells $/ \mathrm{ml}$ for $R$. vitis based on dilution plating immediately

135 after resuspension) and diluted by a factor of $10^{4}$ to generate low density (LD) cultures. $20 \mu$ aliquots

136 of each HD and LD culture were spotted on filters and allowed to dry in a laminar flow hood. Plates

137 were incubated at $32{ }^{\circ} \mathrm{C}$ and $90 \% \mathrm{rH}$. Immediately after spots were dry $\left(t_{0}\right)$ and after $4,8,24,28$ and

13832 hours, filters were removed and placed in a $50 \mathrm{ml}$ flask containing $5 \mathrm{ml}$ of CTT liquid and 139 approximately 10 glass beads ( $3 \mathrm{~mm}$ diameter). Flasks were shaken at $300 \mathrm{rpm}, 32{ }^{\circ} \mathrm{C}$ for 15 minutes

140 to disperse cell populations, which were then dilution-plated into CTT $0.5 \%$ agar. Colonies were 141 counted after $3-5$ days of incubation at $32{ }^{\circ} \mathrm{C}, 90 \% \mathrm{rH}$.

142 Differences in the degree of growth between HD and LD populations at each timepoint $N_{t}$ in the 143 same replicate were calculated as: $\log _{10}\left(N_{t}(\mathrm{HD}) / \mathrm{N}_{0}(\mathrm{HD})-\log _{10}\left(N_{t}(\mathrm{LD}) / \mathrm{N}_{0}(\mathrm{LD})\right.\right.$.

M. xanthus: Following the same protocol as for the growth assay, we let M. xanthus cultures grow on CTT 1.5\% agar in flasks at $\mathrm{pH} 6.0,7.5$ and 8.5 starting from low and high initial densities $(\sim 1.25 \mathrm{x}$ $10^{6}$ (LD) and $\sim 1.25 \times 10^{8}$ (ID) cells $/ \mathrm{ml}$, respectively). After 18 hours, we added $1 \mathrm{ml}$ of CTT liquid to each flask and shook all flasks for 30 minutes at $300 \mathrm{rpm}$ prior to collection of cell-free supernatant from each resuspended culture by filtration $(0.2 \mu \mathrm{m}$ filters $)$. and ID with the six treatments of collected supernatants described above (derived from ID and LD cultures grown on agar at $\mathrm{pH}$ 6.0, 7.5 and 8.5) and CTT liquid as a control. $400 \mu \mathrm{l}$ of each resuspended culture were spread on CTT 1.5\% agar adjusted to $\mathrm{pH} 6.0,7.5$ or 8.5. After 18 hours of incubation, 1 $\mathrm{ml}$ of CTT liquid and $\sim 10$ glass beads ( $3 \mathrm{~mm}$ diameter) were added to each flask and flasks were shaken for $10^{\prime}$ at $300 \mathrm{rpm}$ prior to dilution plating to obtain colony counts.

156 Non-myxobacteria: Non-myxobacterial species were inoculated in liquid CTT media, incubated overnight at $32{ }^{\circ} \mathrm{C}$ at $300 \mathrm{rpm}$, centrifuged at $5000 \mathrm{rpm}$ for $15 \mathrm{~min}$ and resuspended in CTT liquid to the respective high-density (HD) value for each species and then diluted by a factor of $10^{4}$ to generate

159 the respective low-density (LD) treatment. $20 \mu 1$ aliquots of these HD and LD cultures were then 160 individually spotted on a polyamide membrane filter placed on CTT $1.5 \%$ agar with $\mathrm{pH}$ adjusted to 
161 both $\mathrm{pH} 7.5$ (control) and the same acidic $\mathrm{pH}$ value used for the acid-stress growth assays described

162 above and the resulting cultures were incubated for $18 \mathrm{hrs}$. To generate supernatant for the next step of

163 the experiment, filters were then removed from the agar beds, placed in $1 \mathrm{ml} \mathrm{CTT} \mathrm{liquid,} \mathrm{incubated} \mathrm{at}$

$164100 \mathrm{rpm}$ on a gel rocker for 30 minutes, and the filter-treated CTT liquid was then filter sterilized using

165 a $0.2 \mu \mathrm{m}$ filter.

166 The resulting culture supernatants were used to then resuspend LD and HD cultures of the respective

167 non-myxobacterial species, and growth assays were performed to measure the influence of diffusible

168 substances on the growth of LD and HD cultures. To do so, cultures of A. globiformis, M. luteus, $R$.

169 vitis and P. fluorescens that had been incubated in CTT liquid for 48 hours were spun down and

170 resuspended to HD and LD using the supernatant derived from either HD or LD cultures growing at

171 either the respective acid-stress $\mathrm{pH}$ or at $\mathrm{pH} 7.5$, as described above. $20 \mu \mathrm{l}$ of these resuspended cultures

172 were then spotted on a filter placed on CTT agar at the respective acidic $\mathrm{pH}$ for each species and

173 additional samples from the same resuspended cultures were dilution-plated to obtain T0 population-

174 size estimates. Plated samples were then incubated for $18 \mathrm{hrs}$. To obtain population-size estimates at

175 T18, filters were placed in 12-well-plate wells containing $1 \mathrm{ml} \mathrm{CTT} \mathrm{liquid} \mathrm{and} \mathrm{cultures} \mathrm{were} \mathrm{dispersed}$

176 by repeated pipetting prior to dilution plating.

\section{Fruiting-body development}

178 Development assays were performed in Greiner ${ }^{\mathrm{TM}}$ 6-well plates containing $5 \mathrm{ml} \mathrm{pH}$-adjusted TPM

$1791.5 \%$ agar per well, which was poured one day prior to inoculation and kept at room temperature

180 overnight. Vegetatively growing cultures of GJV1 were centrifuged, resuspended in TPM liquid to $\sim 5$

$181 \times 10^{9}$ cells $/ \mathrm{ml}$ and subsequently diluted into two lower density treatments of $\sim 1 \times 10^{9}$ and $\sim 3 \times 10^{8}$

182 cells $/ \mathrm{ml}$. Ten $\mu 1$ aliquots for each density treatment were placed on TPM agar and allowed to dry in a

183 laminar flow hood. After five days of incubation, developmental phenotypes were photographed. Three

184 temporally independent replicate assays were performed for each density-pH combination with two

185 technical replicates performed in adjacent wells within each independent replicate. 
Results

187 Myxococcus survival and growth under pH stress is strongly density dependent

188 Early experiments with the reference strain GJV1 growing on agar surfaces that measured optical

189 density (OD) over time suggested that growth rate was density dependent across a wide range of $\mathrm{pH}$

190 levels, but also that the degree of density dependence might be greater under more acidic and more

191 basic conditions than at more benign $\mathrm{pH}$ levels (Fig. S1). Especially in the acidic direction, growth

192 rate appeared more sensitive to deviation from $\mathrm{pH} 7.5$ (at which the lowest-density populations grew

193 best) at lower cell density, although greatly increased experimental error at the most extreme $\mathrm{pH}$ values

194 obscured estimates in those treatments. To facilitate more direct estimates of population size, we further

195 investigated the effect of acid stress on density-dependent growth by M. xanthus using strain DK3470,

196 which disperses more easily in liquid after growth on agar than GJV1 due to a mutation that reduces

197 production of extracellular matrix components [57,58]. Based on the results with GJV1, we performed growth assays with DK3470 at $\mathrm{pH}$ 5.0,6.0 and 7.5.

199 When cells were inoculated onto CTT agar at low density (LD, $\sim 1.25 \times 10^{6}$ cells $\left./ \mathrm{ml}\right)$ at the three $\mathrm{pH}$

200 levels, viable population size decreased in both acidic treatments ( $\mathrm{pH} 5.0,6.0)$ until no viable cells were

201 detected at later time points, whereas populations grew robustly from the same low density at $\mathrm{pH} 7.5$

202 (Figs. 1, S2). Starting at 100-fold higher density (intermediate density, ID, $\sim 1.25 \times 10^{8}$ cells $/ \mathrm{ml}$ ), viable

203 populations decreased to non-detection at $\mathrm{pH} 5.0$ but grew steadily at both $\mathrm{pH} 6$ and $\mathrm{pH}$ 7.5. Populations

204 initiated at the highest density (HD, $\sim 1.25 \times 10^{10}$ cells $/ \mathrm{ml}$ ) increased only slightly before reaching maximum population size. However, these HD populations reveal positive density dependence of survival in that they did not decrease substantially even at $\mathrm{pH} 5.0$ as did the lower-density populations,

207 but rather remained relatively stable throughout the experiment in all $\mathrm{pH}$ treatments. Thus, under even

208 mild acid stress, cell density determines whether M. xanthus populations survive and grow. These 209 outcomes reflect a strong Allee effect [6] in which populations increase or decrease depending on

210 whether they are above or below a threshold density, respectively. 


\section{A pH-regulated diffusible secretion mediates PDD of M. xanthus growth under acid stress}

212 We tested whether the exported social molecule(s) mediating density-dependent growth of $M$.

213 xanthus under acid stress is diffusible or cell-bound. To do so, we supplemented populations initiated

214 at LD and pH 6.0 - conditions that normally lead to population decline (Fig. 1) - with filter-sterilized

215 supernatant from cultures that had been initiated at LD or ID (same densities as in the Fig. 1 experiment)

216 and incubated at $\mathrm{pH} 6.0,7.5$ and 8.5 for $18 \mathrm{~h}$. As expected, supernatant from all populations initiated at

217 LD, regardless of the $\mathrm{pH}$ at which those populations were incubated, failed to prevent population decline

218 of cultures initiated at LD and $\mathrm{pH}$ 6.0, as did control supplementation with CTT growth medium (Fig.

219 2). However, supernatant from both ID populations incubated at the two lower pH levels induced

220 significant growth of LD populations at $\mathrm{pH}$ 6. These outcomes demonstrate that density-dependent

221 survival and growth by M. xanthus is mediated by a diffusible secretion. Unlike supernatant derived

222 from ID cultures grown at $\mathrm{pH} 6.0$ and 7.5, supernatant from ID cultures growing at $\mathrm{pH} 8.5$ failed to induce growth of LD, $\mathrm{pH} 6.0$ cultures. This latter outcome reveals that the production and/or stability of the diffusible M. xanthus PDD factor is regulated by environmental $\mathrm{pH}$.

The secreted PDD factor might protect from acid toxicity either by increasing environmental $\mathrm{pH}$ or by inducing changes in cellular state that render cells less sensitive to unchanged acidity. To test between these possibilities, we compared the $\mathrm{pH}$ of supernatant from ID, $\mathrm{pH} 6.0$ cultures after $18 \mathrm{hrs}$ of incubation to $\mathrm{pH}$ measurements of the original medium but found no significant change $(p>0.05$, one sample $t$-test). This outcome indicates that the secreted PDD factor exerts its protective effects by a mechanism other than altering environmental $\mathrm{pH}$.

In light of the acid-stress Allee effects on vegetative growth documented above, we asked whether PDD of M. xanthus fruiting body development already known to occur at benign $\mathrm{pH}[26,29]$ increases in strength with increasing acid stress. Populations of the developmentally proficient strain GJV1 were incubated on TPM starvation agar at five $\mathrm{pH}$ levels (pH 5.5, 6.0, 6.5, 7.0 and 7.5) and three initial cell

236 densities (HD, ID and LD, see Methods) and developmental phenotypes were observed. While dark

237 fruiting bodies formed at all five $\mathrm{pH}$ conditions in the HD treatment, the degree of developmental 
aggregation was found to be more sensitive to acid stress at lower densities (Fig. 3). ID populations

239 showed only very slight aggregation at the lowest $\mathrm{pH}$ and LD populations did not even minimally

240 aggregate at the two lowest $\mathrm{pH}$ levels. Thus, the negative effect of decreasing cell density on

241 developmental aggregation is greater under acid stress than at benign $\mathrm{pH}$ levels.

Acid-stress Allee effects are common across the eubacteria domain but appear to be mediated by diverse

mechanisms

Our results with M. xanthus together with results from prior studies $[30,59,60]$ led us to ask whether acid-stress Allee effects are common across the eubacteria domain. Pilot experiments identified acidic $\mathrm{pH}$ ranges at which growth of four non-myxobacterial species - Arthrobacter globiformis, Micrococcus luteus, Pseudomonas fluorescens and Rhizobium vitis - still occurred at least at high density but was reduced relative to less acidic $\mathrm{pH}$. Subsequently, at one $\mathrm{pH}$ level for each species at which high-density growth was reduced, changes in population size by all four species over a $32 \mathrm{~h}$ period were measured in cultures initiated from two starting densities differing by a factor of $10^{4}$ (see Methods). PDD of growth under acid stress was clearly evident in all four species (Figs. 4, S3). In three species $(A$. globiformis, $P$. fluorescens and $R$. vitis), the LD populations decreased while the HD populations increased (strong Allee effects), while in M. luteus the HD populations increased more than did LD populations (a weak Allee effect)(Fig. S3).

To examine whether acid-stress Allee effects are mediated by similar mechanisms across bacterial species, we tested whether, as occurs in M. xanthus (Fig. 2), supernatant from HD cultures of the four non-myxobacterial species mitigates the disadvantage of LD cultures subjected to acid stress relative to HD cultures. HD cultures treated with any supernatant consistently performed better under acid stress in these experiments than the respective LD cultures treated with the same supernatant (Fig. S4), either remaining stable or declining less than the corresponding LD cultures, which consistently decreased significantly due to acid stress. However, unlike HD supernatant from M. xanthus, HD supernatants from the other species did not improve the performance of acid-stressed LD cultures (Fig. S4). This result suggests that the Allee effects observed in these species are mediated either by i) cell-bound rather

264 than diffusible molecules or ii) diffusible molecules that rapidly diffuse away into agar after cultures 
were spotted onto experimental plates and thus have little protective effect under our experimental conditions.

\section{Discussion}

Molecules mediating social interactions play major roles in microbial life histories [e.g. $2,22,23,25,44,45,47,61,62]$. Having found that social molecules greatly mitigate acid stress by the complexly social bacterium $M$. xanthus, we investigated whether social protection from toxic acidity is a widespread trait among prokaryotes. Indeed, all five phylogenetically diverse species examined here exhibited clear positive density-dependence of growth under acid stress. Moreover, additional examples of social protection from $\mathrm{pH}$ stress have previously been reported in yet other individual species

$274[30,38,59,63,64]$. Collectively with those earlier reports, our phylogenetically broad experiments suggest that social forms of protection from toxic acidity are the norm rather than the exception among eubacteria.

Yet despite the prevalence of social protection from acid stress across bacteria, this phenotype has clearly evolved by diverse molecular mechanisms. Streptococcus mutans cells protect themselves against oral-cavity acidity (that they themselves increase) by secreting a quorum-sensing peptide that in turn triggers stress-protective physiological change [38]. Corynebacterium ammoniagenes eliminates toxic acidity in urea-containing medium by secreting urease [30]. M. xanthus does not appear to significantly alter its environmental $\mathrm{pH}$ (at least under our experimental conditions), but does secrete a protective diffusible factor. The four non-myxobacterial species examined here, however, appear to employ non-diffusible protective molecules (or diffusible protectants of a different character than that of M.xanthus), as supernatant from high-density cultures of these species did not protect acid-stressed low-density populations from population decline, as occurred in M. xanthus. Thus, just drawing from our own experiments and the examples of $S$. mutans and C. ammoniagenes, different forms of bacterial social protection against acid stress appear to involve both diffusible and non-diffusible factors and to involve both predominantly cell-level protection and environmental modification. More detailed

290 investigations of the species examined here and other species are likely to reveal yet greater mechanistic 291 diversity. 
High conspecific cell density is the norm for microbes growing as colonies in structured habitats,

293 for example in biofilms $[38,65,66]$, and is thus expected to be a major selective force in most natural

294 contexts, including under both stressful and benign conditions. To fully understand the social lives of

295 microbes, fitness effects of density both i) within stressful ranges of diverse abiotic parameters such as

296 hydration level, oxygen level, $\mathrm{pH}$, salinity, starvation, and temperature and ii) while subject to biotic antagonisms such as interference competition [28], immunity [31] and predation [7] need to be quantified across a broad range of microbes and the molecular mechanisms of discovered Allee effects and their evolutionary causes correspondingly investigated. Intriguingly, the yeast Saccharomyces cerevisiae has recently been found to socially protect itself from temperature stress by secretion of glutathione [33]. Costly production of such abiotic-stress protectants should often be cheatable by nonproducing or low-producing genotypes [27]. Thus, genetic diversity among conspecifics for variation at protectant-production levels due to such exploitation is expected to be common.

Considering the myxobacteria, traits previously shown to depend positively on cell density have been associated, whether directly or indirectly, with motility [67], aggregative fruiting-body development $[26,68]$ or predation [50] - the social behaviours for which the myxobacteria are best known. Additionally, due to strong positive frequency-dependence of interference competition between natural isolates of M. xanthus, high local density should also promote competitiveness in direct cell-cell combat when diverged cell groups meet in the soil [69]. Here we show that simple vegetative growth by M. xanthus under acid stress is dependent on a social trait. Social resistance to $\mathrm{pH}$ stress appears to

311 be independent of other complex M. xanthus social behaviours, as it was documented most extensively

312 here using a strain defective at TFP-based motility and aggregative development.

313 These findings with M. xanthus also have implications for understanding microbial "eco-evo-devo"

314 [70], or how ecological conditions shape the evolution of microbial developmental systems. We found

315 that acid stress amplifies dependence of $M$. xanthus fruiting-body development on cell density beyond 316 that observed at benign $\mathrm{pH}[26,29]$. Specifically, the minimum cell density required to allow 317 developmental aggregation increases with acid stress (Fig. 3). This suggests that stressfully acidic 318 natural conditions select more strongly for traits promoting high local density upon nutrient depletion 319 than do less stressful $\mathrm{pH}$ conditions. Thus, acid stress and potentially other forms of abiotic stress may 
impact how the relationship between density and development (Fig. 3) - including output of spores that

321 subsequently germinate and grow - evolves. Such environmental stresses may thereby select on density-

322 determining traits such as motility behaviour and adhesin production, not only in the myxobacteria but

323 in other aggregative developmental systems as well.

324 In the myxobacteria, spores are often formed within fruiting bodies. Hypothesized benefits of sporulating within elevated, dense groups rather than more individualistically outside of fruiting bodies include increased probability of dispersal to growth-conducive environments and increased spore quality and survival $[2,42,71]$. Another idea proposes that the high density of spores within fruiting

328 bodies enhances germination and subsequent growth after encountering nutrient levels conducive to 329 growth $[42,50,72]$. Consistent with the latter hypothesis, spore germination was recently found to 330 depend positively on density under both benign conditions and under saline stress [27]. Our results

331 suggest that tight packing of spores benefits spore germination and subsequent growth if fruiting bodies encounter acidic conditions.

333 Microbes often modify environmental $\mathrm{pH}$ and in so doing can strongly impact microbial interactions

334 [30]. For example, Escherichia coli generates acidic byproducts from metabolizing glucose, which has

335 been shown to inhibit host colonization by Vibrio cholerae [73]. Our findings suggest that 336 environmental acidification by potential prey may make myxobacterial predatory fitness density337 dependent by a different mechanism than previously proposed. Earlier experiments showed that the 338 growth rate of M. xanthus liquid cultures on large macromolecules that require extracellular hydrolysis 339 for optimal metabolic use is density dependent, presumably because higher concentrations of 340 extracellular enzymes in high density cultures facilitate more rapid access to hydrolized peptides [50].

341 This has often been cited as evidence that myxobacterial predation efficiency is likely to also be density 342 dependent, although the evidence for this hypothesis has remained indirect. Our results suggest that 343 prey metabolism rather than (or in addition to) predator metabolism may cause predation-fueled growth 344 of myxobacteria to be density dependent when myxobacteria encounter prey colonies that have acidified their local environment. 


\section{ACKNOWLEDGEMENTS}

347 This work was supported by U.S. NIH grant GM07690 and Swiss SNF grant 31003A/B-160005 to

348 G.J.V. We thank Kathryn Whitlock and Sébastien Wielgoss for helpful suggestions.

349 COMPETING INTERESTS - The authors declare no competing interests.

\section{AUTHOR CONTRIBUTIONS}

351 All authors designed experiments, analysed data and drafted manuscript components. FF, SP and HP

352 performed experiments; and FF, SP and GJV revised the manuscript. HP performed early experiments

353 that first revealed effects of density on M. xanthus growth and development under acid stress.

\section{REFERENCES}

355 1. Ruxton GD, Sherratt TN. 2006 Aggregation, defence and warning signals: The evolutionary relationship. Proc. R. Soc. B. 273, 2417-2424.

357 2. Velicer GJ, Vos M. 2009 Sociobiology of the myxobacteria. Annu. Rev. Microbiol. 63, 599-623.

358 3. Alexander RD. 1974 The evolution of social behaviour. Annu. Rev. Ecol. Syst. 5, 325-383.

359 4. Arneberg P, Skorping A, Grenfell B, Read AF. 1998 Host densities as determinants of abundance in $360 \quad$ parasite communities. Proc. R. Soc. B 265, 1283-1289.

361 5. Allee WC, Emerson AE, Park O, Park T, Schmidt KP. 1949 Principles of Animal Ecology. W. B. 362 Saunders Co., Philadelphia and London.

363 6. Berec 1, Angulo E, Courchamp F. 2007 Multiple Allee effects and population management. Trends 364 Ecol. Evol. 22, 185-191.

365 7. Kaul RB, Kramer AM, Dobbs FC, Drake JM. 2016 Experimental demonstration of an Allee effect in 366 microbial populations. Biol. Lett. 12, 20160070.

367 8. Stephens PA, Sutherland WJ, Freckleton RP. 1999 What is the Allee effect? Oikos 87, 185-190.

368 9. Courchamp F, Berec L, Gascoigne G. 2008 Allee effects in ecology and conservation. Oxford University Press, New York.

370 10. Williams CK, Lutz RS, Applegate RD. 2003 Optimal group size and northern bobwhite coveys. Anim. Behav. 66, 377-387. 
372 11. Higashi M, Yamamura N. 1003 What determines animal group size? Insider-outsider conflict and 373 its resolution. Am. Nat. 142, 553-563.

374 12. Vander Wall SB, Enders MS, Waitman BA. 2009 Asymmetrical cache pilfering between yellow pine chipmunks and golden-mantled ground squirrels. Anim. Behav. 78, 555-561.

13. Pedersen B, Hanslin HM, Bakken S. 2001 Testing for positive density-dependent performance in four bryophyte species. Ecology 82, 70-88.

14. Cresswell W. 1994 The function of alarm calls in redshanks, Tringa totanus. Anim. Behav. 47, 736738.

15. Sherman PW. 1977 Nepotism and the evolution of alarm calls. Science 197, 1246-1253.

16. Clark BR, Faeth SH. 1998. The evolution of egg clustering in butterflies: A test of the egg desiccation hypothesis. Evol. Ecol. 112, 543-552.

17. Potts M. 1994 Desiccation tolerance of prokaryotes. Microbiol. Rev. 58, 755-805.

18. Bill RG, Herrnkind W. 1976 Drag reduction by formation movement in spiny lobsters. Science 193, $1146-1148$.

19. Sillen-Tullberg B, Leimar O. 1988 The evolution of gregariousness in distasteful insects as a defense against predators. Am. Nat. 132, 723-734.

20. Turner G. Pitcher TJ. 1986 Attack abatement: a model for group protection by combined avoidance and dilution. Am. Nat. 128, 228-240.

21. Pulliam HR. 1973 On the advantages of flocking. J. Theor. Biol. 38, 419-422.

22. Brockhurst MA, Habets MGJL, Libberton B, Buckling A, Gardner A. 2010 Ecological drivers of the evolution of public-goods cooperation in bacteria. Ecology 91, 334-340.

23. Darch SE, West SA, Winzer K, Diggle SP. 2012 Density-dependent fitness benefits in quorumsensing bacterial populations. Proc. Natl Acad. Sci. USA 109, 8259-8263.

24. Velicer GJ, Kroos L, Lenski RE. 2000 Developmental cheating in the social bacterium Myxococcus xanthus. 404, 598-601. cheating supports the coexistence of diverse quorum-sensing alleles. Proc. Natl Acad. Sci. USA $113,2152-2157$. 
26. Kadam SV, Velicer GJ. 2006 Variable patterns of density-dependent survival in social bacteria. Behav. Ecol. 17, 833-838.

27. Pande S, Pérez Escriva P, Yu YTN, Sauer U, Velicer GJ. 2020 Cooperation and cheating among germinating spores. Curr. Biol. 30, 4745-4752.

28. Maldonado-Barragán A, West SA. 2020 The cost and benefit of quorum sensing-controlled bacteriocin production in Lactobacillus plantarum. J. Evol. Biol. 33, 101-111.

29. Kaplan HB, Plamann L. 1996 A Myxococcus xanthus cell density-sensing system required for multicellular development. FEMS Microbiol. Lett. 139, 89-95.

30. Ratzke C, Gore J. 2018 Modifying and reacting to the environmental $\mathrm{pH}$ can drive bacterial interactions. PLoS Biol. 16, e2004248.

31. Landsberger M, Gandon S, Meaden S, Rollie C, Chevallereau A, Chabas H, et al. 2018 AntiCRISPR phages cooperate to overcome CRISPR-Cas immunity. Cell 174, 908-916.

32. Andreu-Moreno I, Sanjuán R. 2020 Collective viral spread mediated by virion aggregates promotes the evolution of defective interfering particles. mBio 11, e02156-19.

33. Laman Trip DS, Youk H. 2020 Yeasts collectively extend the limits of habitable temperatures by secreting glutathione. Nat. Microbiol. 5, 943-954.

34. Dressler MD, Conde J, Eldakar OT, Smith RP. 2019 Timing between successive introduction events determines establishment success in bacteria with an Allee effect. Proc. R. Soc. B 286, 20190598.

35. Smith R, Tan C, Srimani JK, Pai A, Riccione KA, Song H, You L. 2014 Programmed Allee effect in bacteria causes a tradeoff between population spread and survival. Proc. Natl Acad. Sci. USA $111,1969-1974$.

36. Wilson M, Lindow SE. 1994 Inoculum density-dependent mortality and colonization of the phyllosphere by Pseudomonas syringae. Appl. Environ. Microbiol. 60, 2232-2237.

37. Monier JM, Lindow SE. 2003 Differential survival of solitary and aggregated bacterial cells promotes aggregate formation on leaf surfaces. Proc. Natl Acad. Sci. USA 100, 15977-15982.

38. Li YH, Hanna MN, Svensater G, Ellen RP, Cvitkovitch DG. 2001 Cell density modulates acid adaptation in Streptococcus mutans: Implications for survival in biofilms. J. Bacteriol. 183, 68756884. 
39. Bardgett R. 2005 The biology of soil: A community and ecosystem approach. In The biology of soil. Oxford University Press.

40. Hartman WH, Richardson CJ, Vilgalys R, Bruland GL. 2008 Environmental and anthropogenic controls over bacterial communities in wetland soils. Proc. Natl Acad. Sci. USA 105, 1784217847.

41. D’Souza C, Alva PP, Padyana AK, Karunasagar I, Kumar BK. 2019 Unveiling the acid stress response of clinical genotype Vibrio vulnificus isolated from the marine environments of Mangaluru coast, India. Can. J. Microbiol. 65, 681-690.

42. Shimkets LJ, Dworkin M, Reichenbach H. 2006 The myxobacteria. In The Prokaryotes 7, 31-115. Springer, New York, NY.

43. Dawid W. 2000 Biology and global distribution of myxobacteria in soils. FEMS Microbiol. Rev. 24, 403-427.

44. Wu SS, Kaiser D. 1995 Genetic and functional evidence that Type IV pili are required for social gliding motility in Myxococcus xanthus. Mol. Microbiol. 18, 547-558.

45. Jakobczak B, Keilberg D, Wuichet K, Søgaard-Andersen L. 2015 Contact- and protein transferdependent stimulation of assembly of the gliding motility machinery in Myxococcus xanthus. PLoS Genet. 11, e1005341.

46. Berleman JE, Kirby JR. 2009 Deciphering the hunting strategy of a bacterial wolfpack. FEMS Microbiol. Rev. 33, 942-957.

47. Shimkets LJ. 1999 Intercellular signaling during fruiting-body development of Myxococcus xanthus. Annu. Rev. Microbiol. 53, 525-549.

48. Jelsbak L, Søgaard-Andersen L. 2000 Pattern formation: Fruiting body morphogenesis in Myxococcus xanthus. Curr. Opin. Microbiol. 3, 637-642.

49. Rosenbluh A, Nir R, Sahar E, Rosenberg E. 1989 Cell-density-dependent lysis and sporulation of Myxococcus xanthus in agarose microbeads. J. Bacteriol. 171, 4923-4929.

50. Rosenberg E, Keller KH, Dworkin M. 1977 Cell density-dependent growth of Myxococcus xanthus on casein. J. Bacteriol. 129, 770-777. 
51. Velicer GJ, Raddatz G, Keller H, Deiss S, Lanz C, Dinkelacker I, Schuster SC. 2006 Comprehensive mutation identification in an evolved bacterial cooperator and its cheating ancestor. Proc. Natl Acad. Sci. USA 103, 8107-8112.

52. Sun M, Wartel M, Cascales E, Shaevitz JW, Mignot T. 2011 Motor-driven intracellular transport powers bacterial gliding motility. Proc. Natl Acad. Sci. USA 108, 7559-7564.

53. Rodriguez AM, Spormann AM. 1999 Genetic and molecular analysis of $c g l B$, a gene essential for single-cell gliding in Myxococcus xanthus. J. Bacteriol. 181, 4381-4390.

54. Dana JR, Shimkets LJ. 1993 Regulation of cohesion-dependent cell interactions in Myxococcus xanthus. J. Bacteriol. 175, 3636-3647.

55. Morgan AD, Maclean RC, Hillesland KL, Velicer GJ. 2010 Comparative analysis of Myxococcus predation on soil bacteria. Appl. Environ. Microbiol. 76, 6920-6927.

56. Vos M, Velicer GJ. 2006 Genetic population structure of the soil bacterium Myxococcus xanthus at the centimeter scale. Appl. Environ. Microbiol. 72, 3615-3625.

57. Shimkets LJ. 1986 Role of cell cohesion in Myxococcus xanthus fruiting body formation. J. Bacteriol. 166, 842-848.

58. Yang Z, Ma X, Tong L, Kaplan HB, Shimkets LJ, Shi W. 2000 Myxococcus xanthus dif genes are required for biogenesis of cell surface fibrils essential for social gliding motility. J. Bacteriol. 182, $5793-5798$.

59. Matsui R, Cvitkovitch D. 2010 Acid tolerance mechanisms utilized by Streptococcus mutans. Future Microbiol. 5, 403-417.

60. Mates AK, Sayed AK, Foster JW. 2007 Products of the Escherichia coli acid fitness island attenuate metabolite stress at extremely low $\mathrm{pH}$ and mediate a cell density-dependent acid resistance. $J$. Bacteriol. 189, 2759-2768.

61. Lazazzera BA. 2000 Quorum sensing and starvation: Signals for entry into stationary phase. Curr. Opin. Microbiol. 3, 177-182.

62. Redfield RJ. 2002 Is quorum sensing a side effect of diffusion sensing? Trends Microbiol. 10, 365370. 
63. Cvitkovitch DG, Li YH, Ellen RP. 2003 Quorum sensing and biofilm formation in Streptococcal infections. J. Clin. Invest. 112, 1626-1632.

64. Loesche WJ. 1986 Role of Streptococcus mutans in human dental decay. Microbiol. Mol. Biol. Rev. 50, 353-380.

65. Li YH, Tang N, Aspiras MB, Lau PCY, Lee JH, Ellen RP, et al. 2002 A quorum-sensing signaling system essential for genetic competence in Streptococcus mutans is involved in biofilm formation. J. Bacteriol. 184, 2699-2708.

66. Fux CA, Costerton JW, Stewart PS, Stoodley P. 2005 Survival strategies of infectious biofilms. Trends Microbiol. 13, 34-40.

67. Berleman JE, Vicente JJ, Davis AE, Jiang SY, Seo YE, Zusman DR. 2011 FrzS regulates social motility in Myxococcus xanthus by controlling exopolysaccharide production. PLoS One 6, e23920.

68. Kuspa A, Plamann L, Kaiser D. 1992 A-signalling and the cell density requirement for Myxococcus xanthus development. J. Bacteriol. 174, 7360-7369.

69. Rendueles O, Amherd M, Velicer GJ. 2015 Positively frequency-dependent interference competition maintains diversity and pervades a natural population of cooperative microbes. Curr. Biol. 25, 1673-1681.

70. Abouheif E, Favé MJ, Ibarrarán-Viniegra AS, Lesoway MP, Rafiqi AM, Rajakumar R. 2014 EcoEvo-Devo: The Time Has Come. In Landry C., Aubin-Horth N (eds). Ecological Genomics. Advances in Experimental Medicine and Biology, vol 781. Springer, Dordrecht.

71. La Fortezza M, Schaal KA, Velicer GJ. In press. Group formation: On the evolution of aggregative multicellularity. Chapter 6 in Herron MD, Conlin PL, Ratcliff WC (eds). The Evolution of Multicellularity. CRC Press, Boca Raton, FL.

72. Kaiser D. 2001 Building a multicellular organism. Annu. Rev. Genet. 35, 103-123.

73. Nag D, Breen P, Raychaudhuri S, Withey JH, and Freitag NE. 2018 Glucose metabolism by Escherichia coli inhibits Vibrio cholerae intestinal colonization of Zebrafish. Infect. Immun. 86, e00486-18. 
510 Fig. 1. High density allows growth of $M$. xanthus under acid stress that kills low-density

511 populations. Log-transformed ratios of population size $\left(N_{t}\right)$ of $M$. xanthus strain DK3470 over time

512 relative to starting size $\left(N_{0}\right)$ are shown for populations inoculated in media of $\mathrm{pH} 5.0$ (red shading), 6.0

513 (blue) or 7.5 (green) at high (HD), intermediate (ID) and low (LD) density (see Methods). Shading

514 represents $95 \%$ confidence regions $(n=3)$.

515 Fig. 2. M. xanthus growth under acid stress is mediated by a diffusible public good. Supernatants

516 from intermediate-density (ID) cultures of DK3470 grown at $\mathrm{pH} 6.0$ or 7.5 protect low-density (LD)

517 populations from acid stress ( $\mathrm{pH}$ 6.0) and thereby allow population growth (green circles). Control 518 media (CTT), supernatants from LD cultures grown at three tested $\mathrm{pH}$ values and supernatants from ID 519 cultures grown under basic conditions ( $\mathrm{pH}$ 8.5) do not protect LD cultures from population crashes 520 caused by acid stress (red circles). Error bars represent 95\% confidence intervals $(n=3)$.

521 Fig. 3. Strength of PDD during aggregative multicellular development by M. xanthus increases

522 with acid stress. Developmental phenotypes after five days of starvation for populations initiated at three cell densities (HD, $\sim 5 \times 10^{9}$ cells $/ \mathrm{ml}$; ID, $\sim 10^{9}$ cells $/ \mathrm{ml}$; LD, $\sim 3 \times 10^{8}$ cells $/ \mathrm{ml}$ ) and five $\mathrm{pH}$ values are shown. Dark spots are fruiting bodies in which many light-refractive spores have formed whereas light spots are aggregates with fewer, if any, stress-resistant spores.

526 Fig. 4. Growth under acid stress depends on density across highly diverged bacterial species.

527 Growth differences between high-density (HD) vs low-density (LD) populations of four bacterial 528 species under acid stress are shown. Values greater than 0 indicate that the respective HD populations increased more than the respective LD populations by the relevant time point. The y-axis unit reflects

530 a ten-fold difference in the degree of population-size change from the start of the experiment. (See also 531 Fig. S3.) Shaded areas represent $95 \%$ confidence regions $(n=3)$. 
532 Fig. S1. Maximum growth-rate estimates for GJV1 populations measured as highest growth over a 24-

$533 \mathrm{~h}$ period from OD-based growth measurements on CTT agar at nine $\mathrm{pH}$ levels. LD, ID and HD

534 populations are represented by squares, circles and triangles, respectively. Colours indicate acidic, near-

535 neutral and basic $\mathrm{pH}$ ranges (red, green and blue, respectively). Error bars represent 95\% confidence

536 intervals $(n=3-4)$.

537 Fig. S2. DK3470 $\log _{10}(\mathrm{CFU} / \mathrm{ml})$ for HD, ID and LD populations incubated at $\mathrm{pH} 7.5$ (green), 6.0 (blue)

538 and $5.0($ red). Error bars represent $95 \%$ confidence intervals $(n=3)$.

539 Fig. S3. $\log _{10}(\mathrm{CFU} / \mathrm{ml})$ values for $\mathrm{HD}$ and LD populations of $A$. globiformis, M. luteus, P. fluorescens,

540 and $R$. vitis incubated under acid stress for $32 \mathrm{~h}$. Error bars represent $95 \%$ confidence intervals $(n=3)$.

541 Fig. S4. The disadvantage of acid-stressed low-density populations of non-myxobacterial species is not

542 mitigated by supernatant from either high- or low-density (HD or LD, respectively) cultures grown at

543 either acidic $\mathrm{pH}$ or $\mathrm{pH} 7.5$ or by control media (CTT). A. Log-ratio of population size after vs before

$54418 \mathrm{~h}$ incubation under acid stress with the specified supernatant treatment or control. Solid and open

545 circles represent cultures initiated at HD and LD, respectively, that were treated with supernatant from

546 cultures grown under the density and $\mathrm{pH}$ conditions specified below the graphs. Recipient populations

547 were incubated at the same acidic $\mathrm{pH}$ as in the experiment reported in Figs. 4 and S3. Letters indicate

548 statistically distinct mean sets (Tukey's posthoc test $p<0.05)$. B. Differences of log-ratios presented in

549 Fig. S4A between LD vs HD populations. Grey circles represent statistically significant differences in

550 population-size change between LD cultures vs HD cultures resuspended in the same culture

551 supernatant (or CTT control)(one-sample $t$-test for significant differences relative to 0 , multiple-test-

552 corrected $p<0.01)$. Error bars represent 95\% confidence intervals $(n=3)$. 
bioRxiv preprint doi: https://doi.org/10.1101/2021.09.27.461844; this version posted September 27, 2021. The copyright holder for this preprint (which was not certified by peer review) is the author/funder, who has granted bioRxiv a license to display the preprint in perpetuity. It is made available under aCC-BY-NC-ND 4.0 International license.

\section{$553 \quad$ Figure 1}
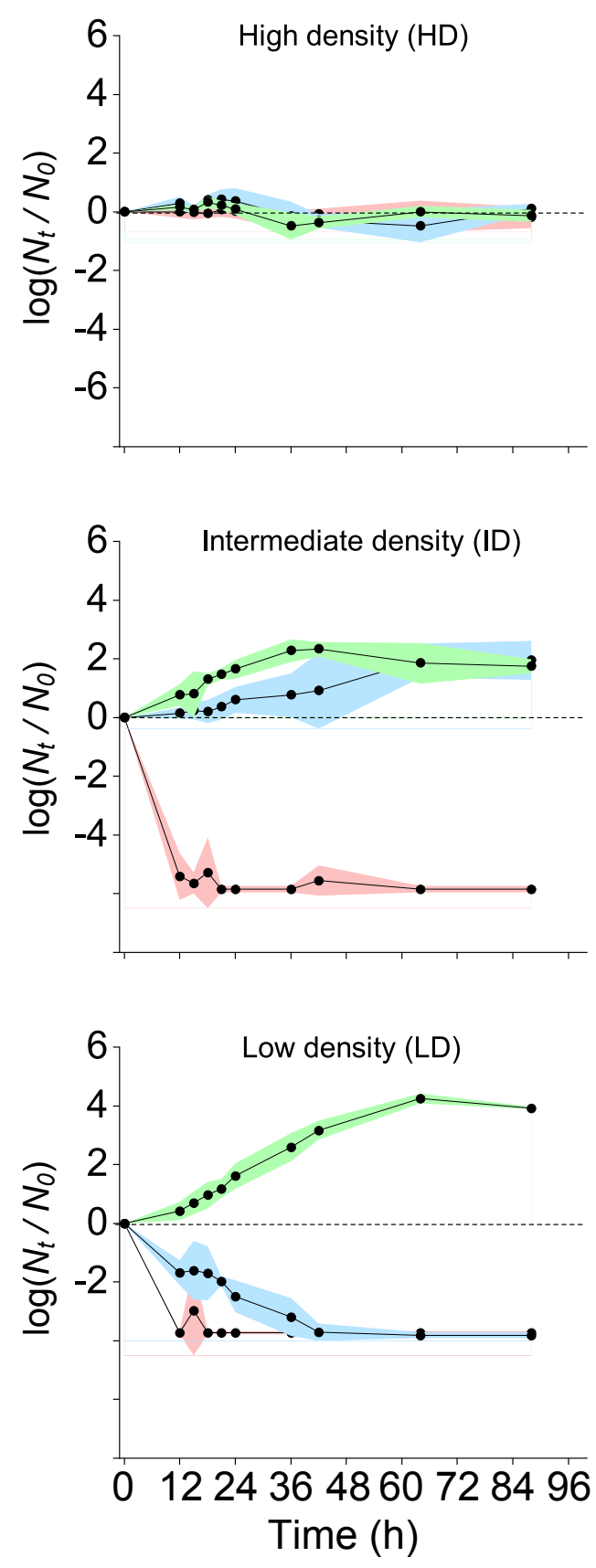
bioRxiv preprint doi: https://doi.org/10.1101/2021.09.27.461844; this version posted September 27, 2021. The copyright holder for this preprint (which was not certified by peer review) is the author/funder, who has granted bioRxiv a license to display the preprint in perpetuity. It is made available under aCC-BY-NC-ND 4.0 International license.

\section{Figure 2}

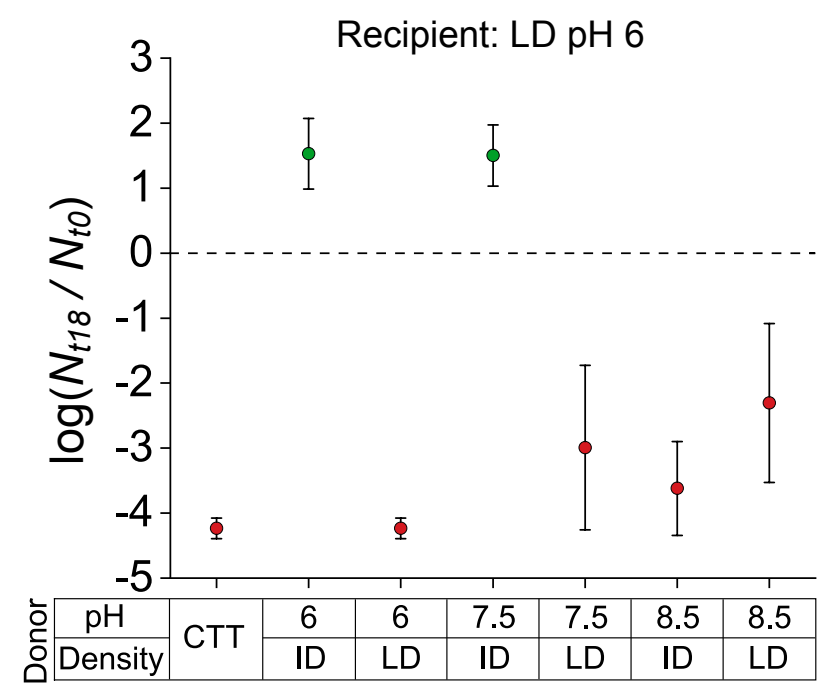


bioRxiv preprint doi: https://doi.org/10.1101/2021.09.27.461844; this version posted September 27, 2021. The copyright holder for this preprint (which was not certified by peer review) is the author/funder, who has granted bioRxiv a license to display the preprint in perpetuity. It is made available under aCC-BY-NC-ND 4.0 International license.

Figure 3

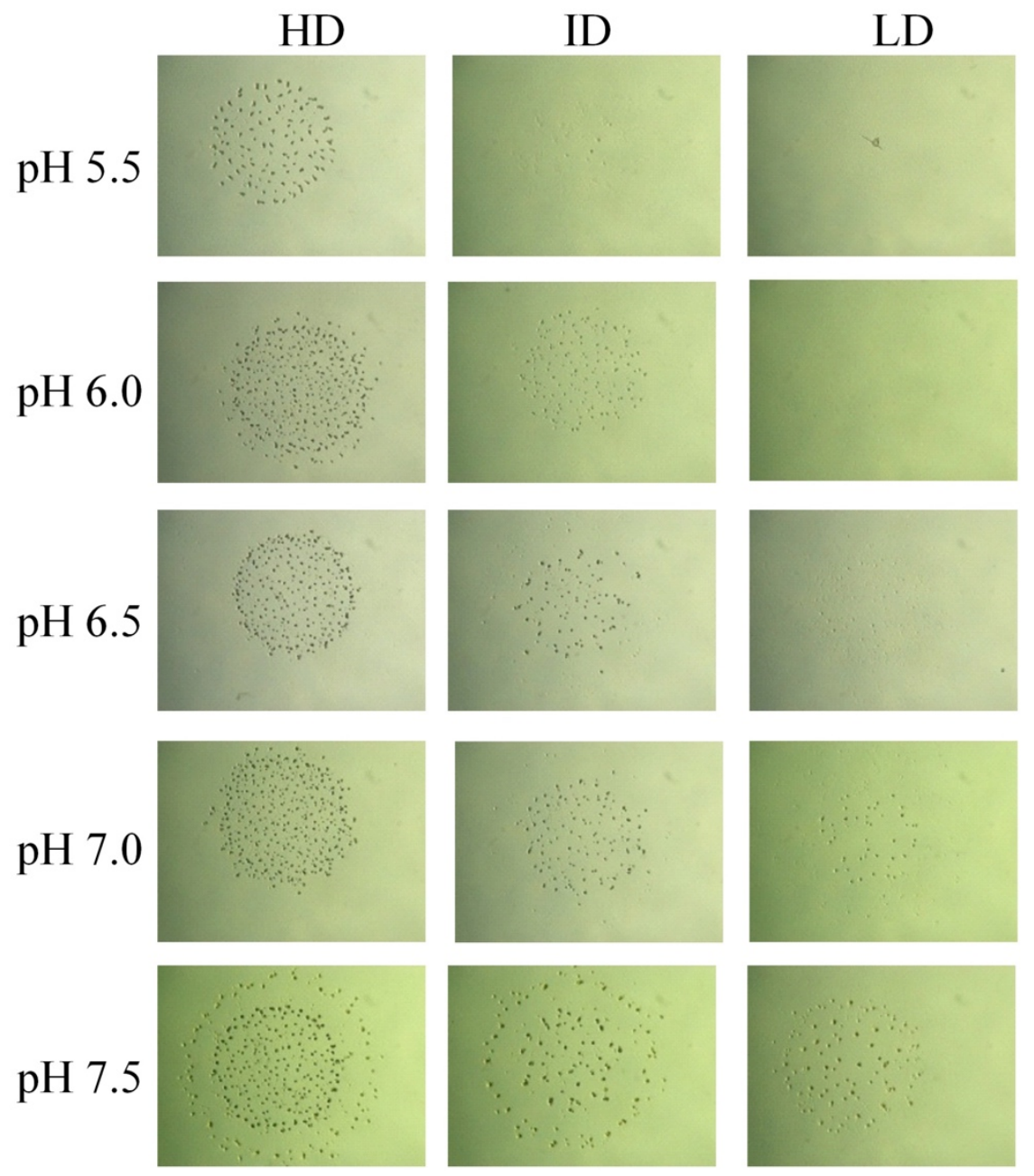


bioRxiv preprint doi: https://doi.org/10.1101/2021.09.27.461844; this version posted September 27, 2021. The copyright holder for this preprint (which was not certified by peer review) is the author/funder, who has granted bioRxiv a license to display the preprint in perpetuity. It is made available under aCC-BY-NC-ND 4.0 International license.

\section{$556 \quad$ Figure 4}
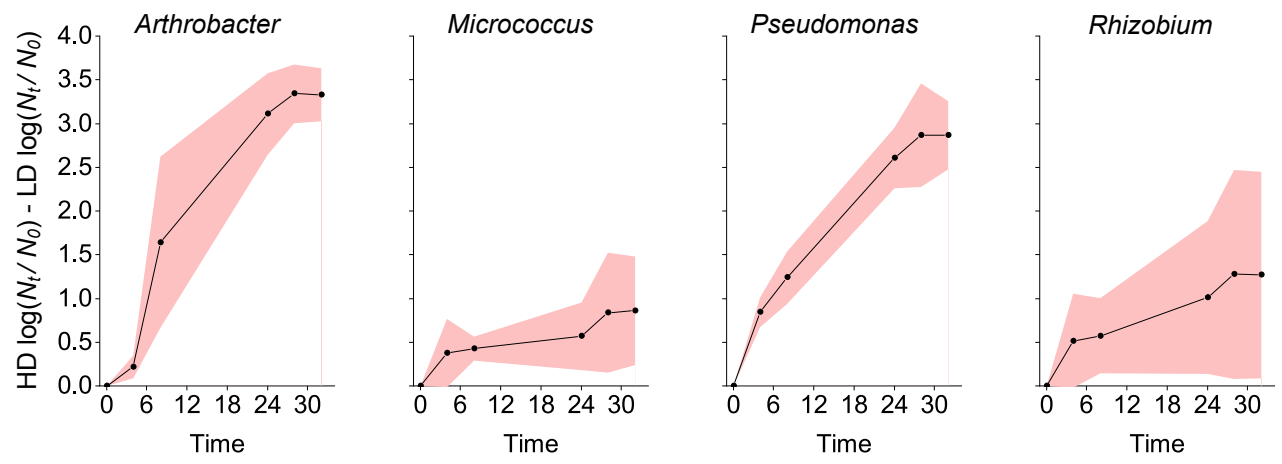
bioRxiv preprint doi: https://doi.org/10.1101/2021.09.27.461844; this version posted September 27, 2021. The copyright holder for this preprint (which was not certified by peer review) is the author/funder, who has granted bioRxiv a license to display the preprint in perpetuity. It is made available under aCC-BY-NC-ND 4.0 International license.

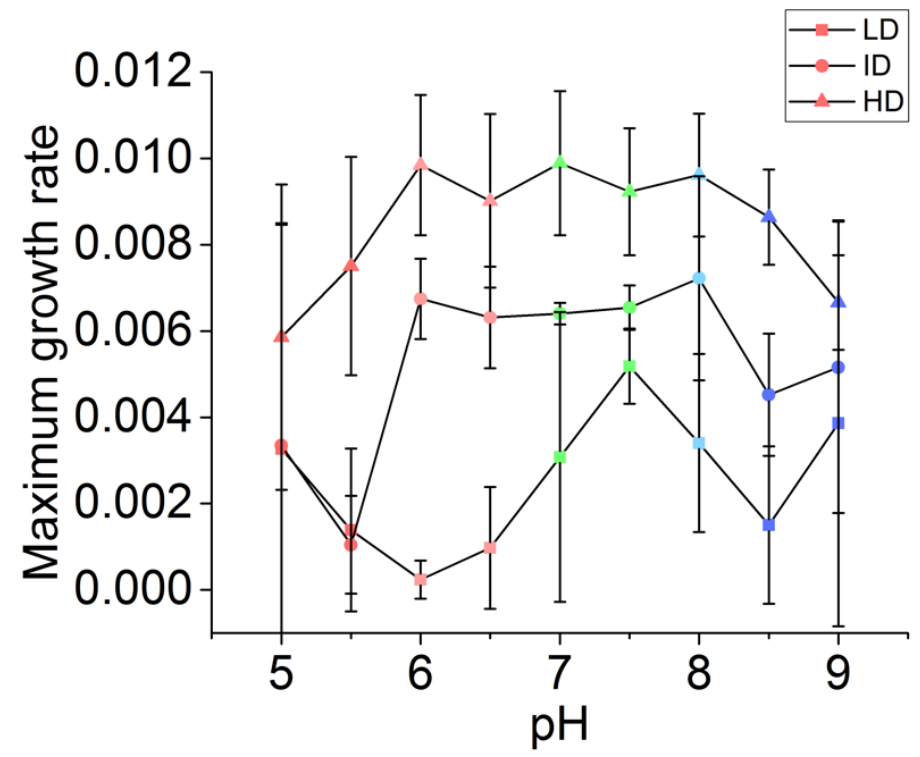


bioRxiv preprint doi: https://doi.org/10.1101/2021.09.27.461844; this version posted September 27, 2021. The copyright holder for this preprint (which was not certified by peer review) is the author/funder, who has granted bioRxiv a license to display the preprint in perpetuity. It is made available under aCC-BY-NC-ND 4.0 International license.

\section{$558 \quad$ Figure S2}

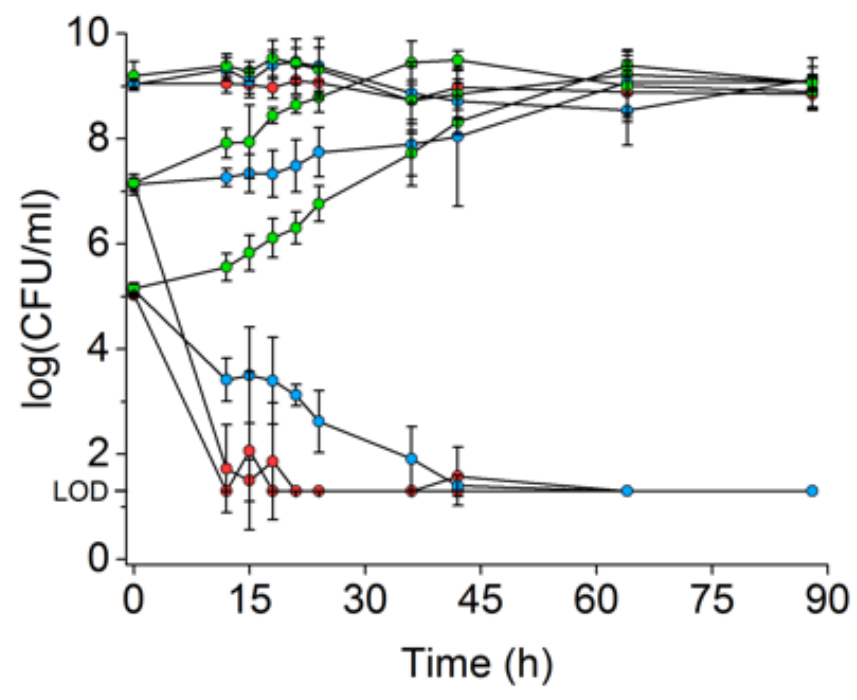


bioRxiv preprint doi: https://doi.org/10.1101/2021.09.27.461844; this version posted September 27, 2021. The copyright holder for this preprint (which was not certified by peer review) is the author/funder, who has granted bioRxiv a license to display the preprint in perpetuity. It is made available under aCC-BY-NC-ND 4.0 International license.

\section{$559 \quad$ Figure S3}
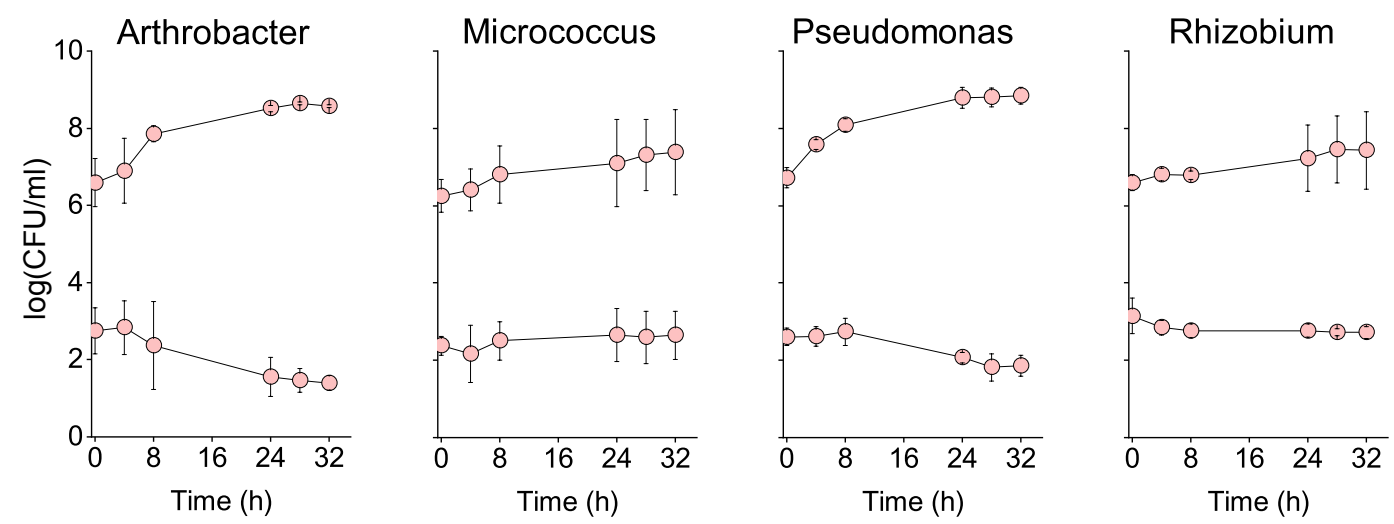

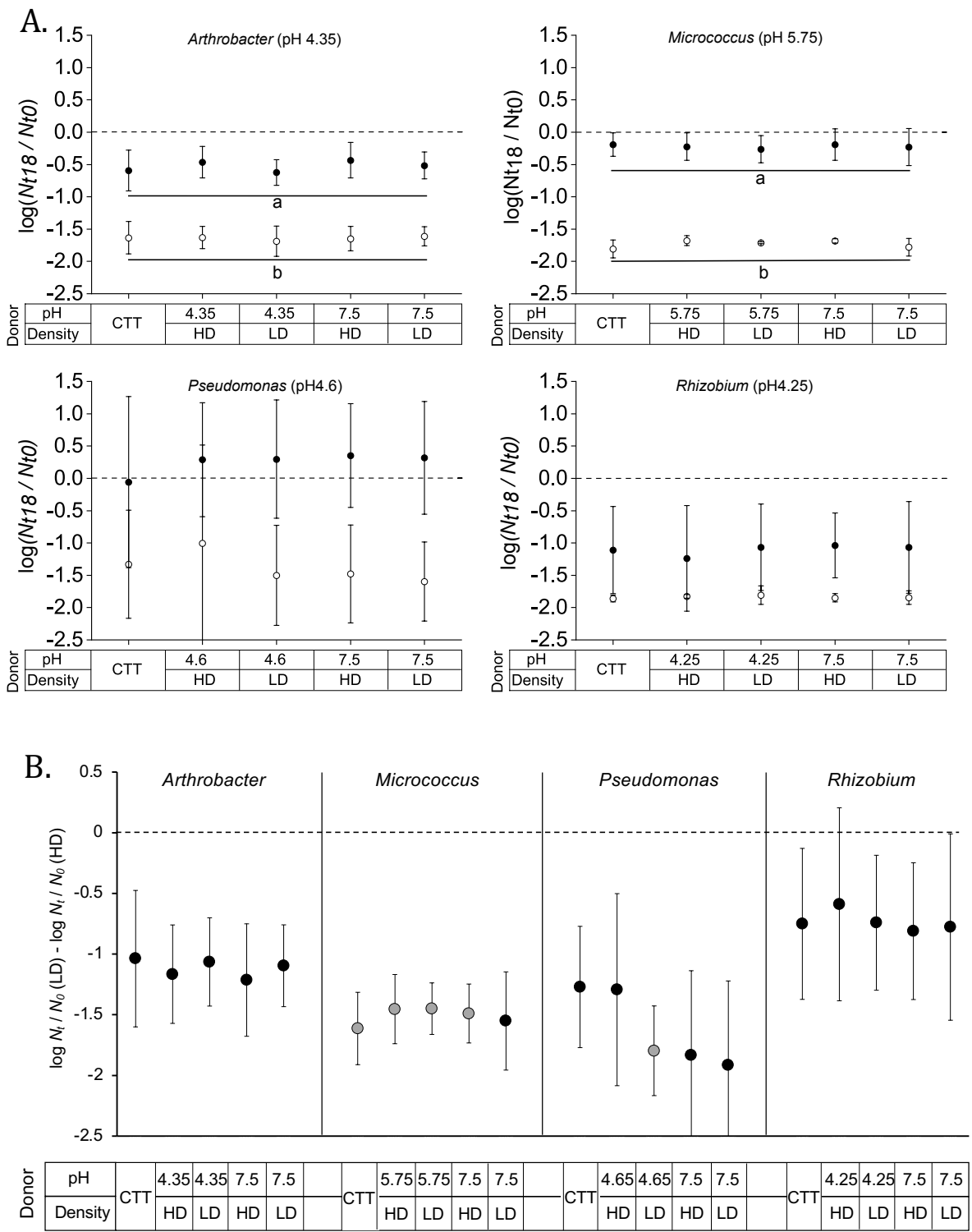